\title{
Mycotoxin incidents associated with cereals: lessons learnt and risk reduction strategies
}

\author{
by Baines, R.N., Manning, L. and Soon, J.M.
}

Copyright, Publisher and Additional Information: This is the author accepted manuscript. The final published version (version of record) is available online via Wageningen Academic Publishers.

Please refer to any applicable terms of use of the publisher.

DOI: https://doi.org/10.3920/QAS2016.1026 
Mycotoxin incidents associated with cereals: Lessons learnt and risk reduction strategies

\begin{abstract}
This paper explores the occurrence and impact of mycotoxins linked to cereals and their indirect impact on human food safety. Epidemiological cases are used to evaluate the impact of mycotoxins on food and feed supply chains. It is shown that mycotoxins pose significant problems and, the implementation and enforcement of legislation, and the development of efficient supply chain strategies including private standards to reduce the risks of contamination and subsequent health issues are considered. Further, the paper identifies the different challenges faced by developing and developed nations in relation to managing the risks associated with mycotoxins relative to local, regional and global trading systems.
\end{abstract}

Keywords: case study, food safety, risk analysis, risk reduction strategies

\title{
Background
}

Mycotoxins are toxic secondary metabolites produced by various fungi that contaminate the feed and food chain. Fungal species involved in contamination of feed and food chains belong to genera such as Aspergillus, Penicillium, Fusarium, Alternatia and Claviceps (Bennett and Klich, 2003; Patriarca and Pinto, 2017). Mycotoxins of major public concern include aflatoxins (AF), ochratoxin A (OTA), fumonisins, (FUM), deoxynivalenol (DON) and zearalenone (ZEA) (Marroquin-Cardona et al., 2014). Mycotoxins are argued to contaminate the diet of a large proportion of the world's population, especially in developing countries (CAST 2003, Wild and Gong 2010). Developing regions are often associated with high humidity and temperature and lack of appropriate storage conditions which contribute to fungal growth and mycotoxin production (Cotty and Jaime-Garcia, 2007). In contrast, strict food safety regulations and modern agronomic practices have reduced mycotoxin contamination in food supply chains of developed regions (Shephard, 2007). The main focus in developed regions continues to be the establishment of legal limits linked to import regulations for food and feed in order to protect humans and livestock. Mycotoxins have been implicated in a number of human diseases (Table 1); however, demonstration of direct connections between the mycotoxins and resulting human illnesses is relatively rare due to the many confounding factors that can influence the pathway of toxins from the fungus to an affected person (Bryden, 2007). As a result, many cases would be most likely classed as 
probable. Table 1 summarises the human diseases, major fungal species that can give rise to mycotoxins in foods,, typical food sources and symptoms.

Insert Table 1 here

The aim of the paper is to explore the occurrence and impact of mycotoxins linked to cereals and their indirect impact on human food safety. Epidemiological cases, both historic and contemporary, are used to evaluate the impact of mycotoxins on food and feed supply chains. Human exposure to mycotoxins can be the result of consuming plant derived foods that have been contaminated (CAST 2003) or from animal derived products where the animal has consumed contaminated plant materials (Boudra et al. 2007; Coffey et al, 2009); exposure may also come from the surrounding environment if air and dust is contaminated with toxins (Jarvis 2002) where it is sometimes referred to as 'sick building syndrome'. The Food and Agriculture Organization (FAO) estimated that $25 \%$ of the world's cereal production is likely to be contaminated with mycotoxins leading to an estimated 1 billion metric tonnes of annual losses in food and feed (Maestroni and Cannavan, 2011). Meanwhile, Binder et al. (2007) reported on a two year survey of animal feeds and feed raw materials, of those mycotoxins known to have an impact on animals (e.g. Fusarium mycotoxins deoxynivalenol [DON], T-2 Toxin, Zearalerone, Fumonisins $\mathrm{B}_{1}, \mathrm{~B}_{2}$ and $\mathrm{B}_{3}$ ); in addition, samples were screened for ochratoxin A and aflatoxin B1 as there is evidence of interactions between these toxins. The results of some 3,000 samples showed that more than half of European samples were contaminated with one or more mycotoxins and one third of Asian and Pacific samples also had measurable concentrations. Global occurrence data on the incidences of mycotoxins in raw cereal grains were reported as 55\% for AF, 29\% for OTA, 61\% for FUM, 58\% for DON and $46 \%$ for ZEA (Lee and Ryu, 2017).

Under ideal conditions the determination of mycotoxicoses in human and animal subjects should depend on the presence of the toxin in suspected food or feed and the patient(s) along with the presence of the fungus and the absence of other disease agents that can cause similar effects (Richard and Thurston 1986). In other words, it is not sufficient to isolate and identify the suspected fungus as it is the concentration of the toxin that is important both in the food source and in the individuals affected. However, such analytical approaches are confounded by a number of factors including: 
- the large number of mycotoxins identified to date and their varied bio-chemical structures;

- the non-uniform distribution of toxins in bulk foods and feed during storage, making sampling a significant challenge;

- expensive laboratory assay procedures, though more recent bio-assay kits are able to qualitatively identify specific toxins;

- low level exposure over time can result in chronic conditions that can be mistaken for other diseases, especially in developing countries where public health resources are limited and mycotoxins are prevalent in food systems, and

- the often sporadic nature of cases making it difficult for health professionals to isolate suspect foods when cases present.

It is interesting to note that most evidence in developing countries today reflect incidents that occurred in developed economies in previous centuries. However, contemporary staple diets are shown to contain mycotoxins and the incidence of human disorders associated with these toxins are prevalent in developing countries, but often the symptoms in the consuming population are not treated as public health cases (Wild and Gong 2010). The diverse nature of mycotoxin contamination is reflected in the wide array of evidence associated with human incidents of mycotoxin related disease collated in Table 2.

Table 2 here

This summary of incidents illustrates a number of points peculiar to mycotoxin poisoning and associated human diseases. It is clear that the majority of human cases identified in the literature, some of which are reported here, have occurred in the developing world. There are a number of factors contributing to this. In tropical conditions of high temperatures and high moisture, including monsoons and flash floods, fungal growth proliferates as does the production of mycotoxins. At the same time, crops are often grown for home consumption under subsistence farming systems with crops often stored in sub-optimal conditions. Furthermore, surplus crops may be sold locally in informal markets with little or no inspection or regulation from public authorities. Such short supply chains make it difficult for government agencies to monitor the health impacts of mycotoxins unless acute cases occur and post disease case studies are carried out. The incidents in Table 2 also demonstrate the relative toxicity of mycotoxins in causing human fatalities; in particular, the high mortality 
rates reported for aflatoxin contaminations and the ergot poisoning incident in Ethiopia lead to vascular restrictions and subsequently gangrene. It is also interesting to note the associations between aflatoxins, Reyes disease and Kwashiorkor. In studies where case and control groups were evaluated, both showed these diseases and the control groups demonstrated the presence of a range of aflatoxins in a number of individuals screened. To further illustrate the challenges in determining whether mycotoxins are indeed the cause of a number of human conditions and diseases; one historic and two contemporary case studies linked to human disease are presented. One contemporary study is from the developing world and the other from the developed world.

\section{Case 1: Salem 1692}

The challenge of mycotoxins to human health has been known since time immemorial with issues such as 'Witchcraft or mycotoxin?', as noted by Woolf (2000), the Dead Sea Scrolls referring to the destruction of 'houses of mildew' and that one of the ten plagues on Egypt was attributed to humans and animals succumbing to contaminated stored grain (Marr and Malloy 1996).. However, perhaps the most infamous incident in the early history of mycotoxins was the Witch Trials in 1692 in Salem, Massachusetts. How does this historic incident stand up to epidemiological case review? In Europe and the United States (US) in the Middle Ages bread, often made with rye, was an important staple especially during the winter months. In early 1692 a number of girls in Salem suffered violent fits, convulsions and complained of itchy skin before lapsing into incoherent rants and hallucinations. Finding no physical cause for these symptoms, the local doctor considered the incidents to be witchcraft. By September of that year, 140 suspected witches had been arrested and 19 executed. We can derive from this, other cases and related evidence point to a causal agent. On the one hand the incidents stopped in the summer months of 1692 which was an unusually dry period. Secondly, the preceding summer was recorded as a warm and damp season which was ideal for fungal growth. Finally, most of the cases were from the west of the village, which was a marshy area and thus more prone to fungal growth (Caporael 1976). To add to this case, historians are aware of several incidents of mass insanity in medieval Europe (often termed St. Anthony's Fire) (Lee, 2009). However, it was not until nearly three hundred years later that a plausible link was postulated for the Salem case by Caporael (1976). More recently, toxicologists have identified that a number of grasses and cereals including rye can be infected by species from the genera Claviceps whose complex life cycle results in developing plant ovaries becoming masses of fungal tissue which harden into sclerotia, similar to hard 
tubers (Eadie, 2003; Schiff, 2006). Sclerotia can be harvested along with the grain and if not removed e.g. by beating, sieving or other separation process, can then contaminate the food chain (Dellafiora et al., 2015; Eadie, 2003). Sclerotia contain ergot alkaloids that can cause gangrenous ergotism with symptoms such as circulation disorders and convulsive ergotism causing nervous disorders, spasms, and hallucinations (see Hulvova et al., 2013; Mulac and Humpf, 2011). The witchcraft trials of 1692 in Salem and in Finnmark, Norway in the $17^{\text {th }}$ century have been studied retrospectively and revealed that ergot alkaloids from Claviceps purpurea were responsible for the ergotism disease in humans (Alm, 2003; Dellafiora et al., 2015; Dellafiora and Dall'Asta, 2017). In seeking to retrospectively determine the cause of food poisoning incidents, evidence presented can lead researchers to consider progressing from suspected causal agent, through probable causal agent to finally confirm the agent responsible. How does the evidence from the Salem case stand up to this scrutiny? The case definitions of Belson et al. (2005) have been adapted to the mycotoxin outbreak in Salem:

- Suspected a case in which a potentially exposed person is being evaluated by health-care workers or public health officials for poisoning by a particular chemical agent (Belson et al. 2005). In the Salem case the exposed people were evaluated by a doctor; however, no agent was suspected or determined and an alternative narrative was postulated and believed by the community.

- Probable a clinically compatible case in which a high index of suspicion exists for chemical agent exposure or an epidemiologic link exists between this case and a laboratory-confirmed case (Belson et al. 2005). By piecing the evidence together retrospectively then it can be argued that there was a high probability of ergot infestation of rye in Salem, especially in the western marshy fields due to the warm and wet summer of 1691 In addition, the symptoms recorded in the trials and times of ingestion are consistent with ergot poisoning from stored grain. Finally, the use of new grain in the dry summer of 1692 was less likely to have been infected.

- Confirmed a clinically compatible case in which laboratory tests of environmental samples have confirmed exposure (Belson et al. 2005). This is not possible in the Salem case as no samples of rye or bread for cross referencing were taken or stored and no food diaries were logged. 
This aflatoxin outbreak in Kenya was one of the most severe cases globally with 317 case patients in seven districts and 125 deaths (CDC 2004). The outbreak was caused by the S strain of Aspergillus flavus (Probst et al., 2007). In this case, maize harvested in the offseason, with early rains was implicated. During preliminary examinations of food collected, aflatoxins were found at high levels especially in locally grown maize. A joint Kenyan and Centre for Disease Control and Prevention (CDC) team then conducted patient interviews and reviewed medical records in health facilities dating back to January of the same year. Any case presenting acute jaundice after January in the affected provinces were listed as potential aflatoxin poisoning. In addition, any patient diagnosed with jaundice at Kenyatta National Hospital that had not got a history of chronic liver disease or other causes of jaundice were also listed as suspected cases (CDC 2004). Reported cases increased during April and continued through to mid-July. Age data was collected on just over 300 patients and showed that $22 \%$ were under 5 and 29\% were 5-14 years; in other words, almost half of those affected were children and juveniles.

The study also carried out a case control study on 80 controls (healthy) and 40 cases in the of pet deaths (Azziz-Baumgartner et al., 2005).

In response to this outbreak, the Kenyan Government provided replacement food to affected districts and advised residents not to eat maize and other foods suspected of being mouldy. Food inspections were carried out and any suspected foods were removed, destroyed and 
replaced. Following on from this, surveillance for aflatoxin poisoning had been extended to other parts of Kenya by the Ministry of Health and screening of maize in store for aflatoxins has been increased (CDC 2004). As an aside to the public response, some concerns were raised over the safety of alternative maize provided by the government as samples taken at the time showed that $55 \%$ of publicly stored grain had aflatoxin levels above $20 \mu \mathrm{g} / \mathrm{kg}$ (Lewis et al., 2005; Muture and Ogana, 2005) and 35\% had levels above $100 \mu \mathrm{g} / \mathrm{kg}$. However, these were significantly lower than those of local markets in the affected districts that were in some cases in excess of $8000 \mu \mathrm{g} / \mathrm{kg}$ (Lewis et al., 2005).

What lessons can be learned from this case? Maize is the major staple food in Kenya and accounted for $40 \%$ of the population's daily food intake. This means that Kenyans are potentially exposed to regular doses of aflatoxins through their staple diet (Probst et al., 2010). High levels of aflatoxin was found in maize samples (some in excess of $8,000 \mu \mathrm{g} / \mathrm{kg}$ when the regulatory level is $20 \mu \mathrm{g} / \mathrm{kg}$ ). The outbreak was caused by the S strain of A. flavus a strain that was not previously found in Africa. The S strain consistently produced larger amount of aflatoxin (Probst et al., 2007). Both the high amount of aflatoxin and regular doses of maize summatively led to patients consuming higher concentrations of aflatoxin. Evidence of clinical illness was grounded in the use of a sound rule base to separate out other factors that may have caused jaundice; clusters of cases were identified within households who would have consumed the same samples of maize; case patients and controls were interviewed and samples of blood and foods were taken for analysis; and there were also reports of animal deaths where they had consumed the same maize as affected householders. The government implemented a corrective action strategy to remove contaminated food and replace this with safer foods and from a preventative point of view, the government of Kenya implemented screening for aflatoxins symptoms through public health facilities and also increased screening of stored maize. Maize from affected regions are destroyed and replaced (with grains from less affected regions). Public health authorities should be aware of potential contaminated maize entering the distribution system leading to continuous exposure to aflatoxin (Lewis et al., 2005).

In epidemiological terms, this case would be classed as being a confirmed case. A final benefit that accrued as a result of this case was the willingness of national and international bodies to co-operate in building capacity and the outbreak provided valuable field training for Kenyan public health workers under the mentorship of the CDC. The incident and subsequent 
investigations also provided case workers with an opportunity to trial novel approaches to epidemiological studies.

\section{Case 3. Gastrointestinal Illness in US School Children Linked to Eating Burritos}

Between October 1997 and March 1998, three outbreaks of gastrointestinal illness in schools were traced back to one company and were linked to burritos containing either: chicken and bean, pork sausage and egg or beef. A further 13 outbreaks in schools from between May and October 1998 were traced back to a second company producing beef and pinto bean burritos (CDC 1999). Both companies used wheat flour to make the tortillas; furthermore, all burritos were distributed to six of the seven affected States as frozen pre-packed product apart from Florida where the fillings were prepared locally. The outbreaks affected 1908 persons from 125 schools (Steinberg et al., 2006) Symptoms include nausea, vomiting, headache and abdominal cramps and occurred within an hour of consuming a burrito. Although no one was hospitalised and no one died, this group of incidents showed how epidemiological patient studies can be used to determine the likely cause of such illnesses. Even when links to a given source are not statistically proven, it is important that government and industries work together to reduce food safety risks. As part of the epidemiological investigation case control studies were set up. The first school showed that $57 \%$ of case and $13 \%$ of control cases ate burritos. In a second school, $85 \%$ of case and $33 \%$ of control cases ate burritos. In both schools, the fillings were made locally and only the tortillas were common to one of the companies under suspicion. The case study also had to identify possible causes of the symptoms presented as a number of agents could be responsible and had to be eliminated. For example, Staphylococcus aureus and Bacillus cereus both produce toxins linked to food poisoning; however, headaches are not normally associated with these and the incubation periods were longer compared to the observed outbreak.. Evidently, food samples from 5 outbreaks were also negative for the pathogens.. Heavy metal contamination could have also caused some of the symptoms; however, none of these were at high levels in the burritos sampled. Previous outbreaks due to ingestion of cereal grains contaminated with DON occurred in China between 1961 - 1985. Patients suffered from similar clinical manifestations such as nausea, vomiting, headache, dizziness and abdominal cramps (Luo, 1988a). Another outbreak in India were caused by consumption of bread made with wheat contaminated with trichothecene mycotoxins. Patients also suffered from abdominal cramps within 15 minutes to an hour after consumption of the bread (Bhat et al., 1989). This led the US investigators to suspect natural toxins, in particular DON as other studies had shown such 
links. Sampled burritos showed DON levels to be within the FDA advisory limit of $1 \mathrm{ppm}$ for finished wheat products; however, children are more vulnerable to such toxins since they consume more of the suspect food than adults when expressed as amount of food consumerd per kg body weight. This result in higher exposures to potential mycotoxins from eating an equivalent amount (Raiola et al., 2015). The companies implicated in supplying contaminated tortillas, both use different raw material suppliers and no common first line supplier was identified. Therefore, it was not determined whether any ingredients were of common origin or shared in any way. Although the link was not proven, the US Department of Agriculture (USDA) requested that both companies initiate national recalls and as a result some two million lbs of burritos were either withheld from distribution or recalled (CDC 1999).

What lessons can be learned from this case? Again the approach was based on the patient epidemiological case studies. The incidents of food poisoning in the schools initiated patient-case studies to be carried out; samples of product were collected and analysed though they were found to be within FDA limits for adult consumption. The symptoms displayed were assessed against a range of causal agents and then each was assessed for probability. Traceback studies were carried out to identify companies' that may have supplied contaminated product. Based on lessons learnt from similar outbreaks in other countries i.e. China and India, mycotoxin food poisoning from DON was considered the most likely cause in these cases. From an epidemiological perspective these cases would be classified as 'most' probable. Furthermore, although mycotoxin poisoning was not proven in these cases, it is important to note that the government requested a product recall (a precautionary approach) and the companies in question complied, as not to do so may have harmed their reputations and hence future business.

In order to carry out such a recall, industry must have effective product trace and recall systems in place that can be embedded into food safety management systems. In this incident, traceability systems and associated records were crucial. Limited shipping records for affected burritos may have hampered further investigation as some lots were not listed (Steinberg et al., 2006). Within the US food industry this may be enforced for high risk foods by legislation mandating the need for hazard analysis critical control point (HACCP) plans or may be a condition of supply under a number of global and national private food standards (Baines 2009). Although HACCP systems are considered to be problematic at the primary production level, particularly the identification of robust critical control points 
(CCP) for the prevention or reduction of hazards and associated record keeping for measures taken, it is still important to have traceability and recall systems in place. Good Agricultural Practice (GAP) is an integral part of food safety at the primary production level, but continuous food safety issues and contaminations may warrant further investigation. Hence this triggers the question: "Is this issue of mycotoxins a call for HACCP based on-farm food safety management systems?" If yes, this will then lead to the critical question: "Is a true HACCP plan possible?". Whilst a true HACCP plan may be possible for addressing chemical hazards (MacDonald 2005, Soon et al. 2012), HACCP is not only about elimination of hazards, but also emphasises risk reduction of biological, chemical and physical hazards. This will be very much relevant to the risk reduction strategies to be applied at the primary production level for mycotoxin reduction. Given the understanding of the range of mycotoxins and the impacts they can cause on human and animal health shown in this paper, allied to the value of patient case studies to determine actual causes of illness or disease; the next section of this paper considers how the risks associated with mycotoxins can be mitigated.

\section{Risk Reduction Strategies}

The first step in reducing the risks associated with mycotoxins is to develop standards for the maximum limits of these natural toxins. These standards need to be linked to the best scientific evidence on what concentrations of toxin are acceptable or not acceptable. This is not a simple task as a number of factors have to be taken into account to determine risk levels such as: age and health of individuals; whether ingestion or exposure is at a low level over long periods i.e. accumulative or higher doses in a short time span; the impact of environmental conditions on the presence and growth of fungi; and the availability of technology to separate, reduce or denature toxins before food or feed is consumed. It is also important to remember that exposure may come from environmental exposure to spores and toxins as well as through ingestion.

Prior to developing and enforcing maximum limits, risk assessment of mycotoxins is the primary scientific basis to determine food safety limits (van Egmond et al., 2007) such as risk assessment of OTA in the US (Mitchell et al., 2017), DON in Norway (Sundheim et al., 2017) and various mycotoxins in Spain (Quiles et al., 2016; Saladino et al., 2017). Similarly a number of studies reported risk assessments of mycotoxins in maize in Zimbabwe (Hove et al., 2016), groundnuts in Nigeria (Oluwawapelumi et al., 2017) and spices in Sri Lanka 
(Jacxsens et al., 2016). Risk assessments are carried out for one mycotoxin, but most fungi are able to produce several mycotoxins at the same time. Similarly, food commodities can be contaminated by several fungi or animal feed made from different grains or sources (Streit et al., 2012), further complicating the mechanisms for risk assessment. Humans and animals can be exposed to a combination of low level mycotoxins. These considerations collectively highlight the challenges of risk assessing multiple mycotoxins in food (Assuncao et al., 2016; Grenier and Oswald, 2011). In addition to studying the interactions of multiple mycotoxins, research on modified forms of mycotoxins (also known as masked mycotoxins) has increased (De Saeger and van Egmond, 2012). Masked mycotoxins are metabolites of the parent mycotoxin formed in the fungus or plant e.g. by conjugation with a polar compound (CONTAM, 2014). It occurs when the mycotoxin conjugate was not detected in routine food or feed testing, but contributed to the total mycotoxin content (Gareis et al., 1990). Recent studies by Dellafiora et al. (2017), Gratz et al. (2017) and De Boevre et al. (2013) contribute to toxicological data and setting up of future regulations (Dellafiora and Dall'Asta, 2016).

As many food and feed raw materials are traded globally, it is important to set minimum rules for mycotoxin levels in line with international trade. This is the responsibility of the Codex Alimentarius Commission (CAC). Established in the early 1960's under the Food and Agriculture and World Health Organisations, Codex's role is to elaborate minimum international food safety regulations and then seek approval for these from member countries (Berg 2003). Risk management associated with chemical contaminants including mycotoxins are dealt with by the Codex Committee for Food Additives and Contaminants (CCFAC), a sub-committee under the CAC. However, the body responsible for the risk assessment component is the Joint Expert Committee on Food Additives (JECFA) who provides scientifically based evidence of the toxicity of chemicals and is charged with establishing safe levels for human consumption. From this information General Standards are developed through a stepwise procedure involving expert committees and national bodies. For mycotoxins the standard is 'The General Standard for Contaminants and Toxins in Food' (CAC, no date) which is updated annually. This standard was accepted by the CAC in 1997 (FAO 2000) with annexes to cover:

- Criteria for the Establishment of Maximum Limits in Food

- Procedure for Risk Management Decisions

- Format of the Standard 
- Annotated list of Contaminants and Toxins, and,

- The Food Categorisation System to be used.

Such standards set maximum limits for toxins using the ALARA acronym - 'As Low As Reasonably Achievable'. International action is based on meeting certain criteria that including that the substance in question is shown to be: in the food or feed at certain levels as determined by reliable analysis; is of toxicological concern at this level; the food or feed is sufficiently important in the potential consumption of the substance; and, the food/feed is traded internationally (Gawalko et al. 2009).

Codex standards are designed to define the minimum legal standards for international trade and are often then used as the basis for national legislation. Furthermore, should member countries be in dispute over whether respective legislation is acting as a trade barrier, Codex standards are often referenced in arbitration, though this process is managed under the World Trade Organisation (WTO). As stated above, national legislation in many countries is based on Codex principles but may be set at more stringent levels depending on the expert evidence put forward by national expert committees or at the Trading block level. As an example, significant legislation has been developed in the European Union and is beyond the scope to reference in full here. However, the European Commission, the Joint Research Centre and the Institute for Reference Materials and Measurements jointly publish summary technical notes for government and industry (Lerda 2011).

Where food and feeds are produced and used within a particular jurisdiction, then the level of mycotoxin contamination deemed to be acceptable or unacceptable will be clearly defined in legislation and material will be sampled and analysed by public inspection agencies. In some regions this may be supplemented by private standards that are often equivalent or more stringent than those set by legislation. However, when food and feed is traded internationally, then different levels of 'acceptable contamination limits' may be enforced. As a rule of thumb, any producer of grains and pulses intended for the international market and any agribusiness trading in raw and finished products should be aware of the limits set in the final destination country or trading block. To exemplify this point, the acceptable levels of aflatoxins are compared for the US, the largest exporter of agri-food products, and the EU, the largest importer of agri-food products (Table 3). 
436• Alert notifications: when a food, feed or food contact material presenting a serious risk is on 437

Insert Table 3 here

This indicative data on mycotoxin limits in cereals, pulses, nuts, milk and animal feed shows that the levels imposed in the EU are more comprehensive and restrictive. In terms of aflatoxins, the US restricts levels of aflatoxin $\mathrm{B}_{1}$ while the EU refers to both aflatoxin $\mathrm{B}_{1}$ plus total aflatoxins $\left(B_{1}, B_{2}, G_{1}, G_{2}\right)$. Moreover, the limits set in the EU are 10 fold more restrictive. In terms of aflatoxin $\mathrm{M}_{1}$ in milk, the EU limits are also 10 fold lower. These lower acceptable levels are also reflected in maximum limits in domestic animal feed with EU levels 2-5 fold lower than the US. In the late 1960s, US FDA set an action level for aflatoxins at $20 \mu \mathrm{g} / \mathrm{kg}$ for all foods including animal feeds. However, animal feeding studies demonstrated that levels of aflatoxins above 20 could be fed to certain food-producing animals without harming the health of these animals and consumers of food derived from the exposed animals. Thus, on the basis of these scientific studies, FDA revised its actions level for animal feed products. There exist stark differences between US and EU standards and this may lead to potential trade implications.

The notification and enforcement of food and feed legislation in the EU is through the Rapid Alert System for Food and Feed system (RASFF). This provides EU food and feed control authorities with shared information about measures taken in responding to serious risks detected in food or feed. Member States are therefore able to act more rapidly and in a coordinated manner in response to a health threat caused by food or feed. RASFF is made up of clearly identified contact points in the Commission, European Food Safety Authority, and European Environment Agency, and at national level in member countries including port and airport authorities (RASFF 2015). The output of the system is RASFF notifications that report on risks identified in food, feed or food contact materials that are placed on the market in the notifying country or detained at an EU point of entry at the border with an EU neighbouring country. The notifying country reports on the risks it has identified, the product and its traceability and the measures it has taken. After verification by the Commission, notifications are transmitted to all contact points under one of the following types of notifications (RASFF 2015): the market and when rapid action is or might be required such as withdrawal or recall. The 
notification aims at giving all the members of the network the information to verify whether the concerned product is on their market, so that they can take the necessary measures.

Information notifications: concerns a food, feed or food contact material for which a risk has been identified that does not require rapid action either because the risk is not considered serious or the product is not on the market at the time of notification. The EU defines two types of information notification: information notifications for followup if a product is or may be placed on the market in another member country: and information notifications for attention if a product is present only in the notifying member country; or has not been placed on the market; or is no longer on the market

Border rejection notifications: concerns consignments of food, feed or food contact material that was refused entry into the Community for reason of a risk to human or animal health or to the environment if it concerns feed.

The RASFF system also allows for follow up notifications which refer to previously notified consignments in order to add information to the original notification such as information on hazards, product traceability or measures taken. Due to the global scale of cereal and pulse trade and the dominance of northern hemisphere agribusinesses, the levels of mycotoxins set for global trading are effectively those of the US or the EU depending on final destination of shipments. Indeed, shipments destined for the EU that might exceed the more restrictive limits may be diverted to the US or 'dumped' in third countries with less restrictive limits or poorly developed enforcement. This leads us to a questioning of what the size and scale of the problem is in internationally traded cereals and derived products. Imposing stricter regulations would result in economic losses in certain countries. For example, Wu (2004) demonstrated that by implementing an international fumonisin standard $<0.5 \mathrm{ppm}$ would result in US\$300 million export losses by the US, Argentina and China (top corn exporting countries). Stricter limits may also mean that countries may export the best quality crops whilst poor quality crops are kept for domestic consumption hence increasing internal country health risks (Wu, 2004).

In addition to EFSA and RASFF, the establishment of the European Union Reference Laboratory (EU-RL) and European Standardization Committee (CEN) with validated methods helped to facilitate the implementation of EU legislation in monitoring mycotoxins in food and feed (EU Science Hub, 2016; FAO, 2004). Projects such as BioCop resulted in 
471 development of novel methods for early detection of mycotoxins (EC, 2011) whilst MoniQA provided a platform for experts to harmonise worldwide food safety and quality monitoring and control strategies (MoniQA Association, 2017). These pan-European projects are important to ensure the safety and quality of the food and feed supply chain.

\section{Risk Reduction Strategies at Supply Chain Level}

477 Given the number of notifications in the EU for example that relate to cereals and mycotoxins, a key challenge is for public administrations and food supply chains to carry out appropriate risk characterisation strategies in order to inform food and feed safety policies and reduce risks and liability in food trade. Characterising food safety risks in order to inform both policy options and supply chain process controls should follow the same steps but with different operational outcomes. These steps include:

- Risk assessments: Systematic evaluation of all relevant information to quantify the magnitude, exposure and probability of a potential food hazard to individuals or populations. This includes hazard identification (mycotoxins), characterisation (effect on humans and animals), exposure assessment (consumption of mycotoxins and dose effects) and risk characterisation (the impact on target consuming population including vulnerable individuals) (Kuiper-Goodman, 2004).

- Risk management: The process of weighing policy or private standard alternatives against the risk assessment in order to set appropriate regulatory measures and control options (Kuiper-Goodman, 1999). In developing options, it is also critical for public administrations to also weigh up public health, economic, social and political consequences; equally, the private sector through various standards will primarily evaluate food safety risks and liability whilst also considering economic and corporate issues. In both cases this contributes to risk characterisation.

- Risk communication: The exchange of relevant information, including uncertainties and precautionary approaches, on risk management decisions taken and the implications for key stakeholders (van Dijk et al., 2008). In the case of public administrations this may include public health officials, industry and consumers; in contrast, the private sector will largely operate through inspection and certification mechanisms to inform business to business communications as opposed to business to 
In order to reduce the economic and health consequences of mycotoxin contamination in cereals and other crops across supply chains, a number of intervention strategies can be employed along with assessment of key risk factors from crop production to final consumer purchase. The aim of such strategies is to ensure that the food or feed product has the lowest practical mycotoxin concentrations. While it is beyond the scope of this review to develop specific mycotoxin strategies, it is important to note that the toxins in question are produced by fungal species that are in turn influenced by local environmental factors, especially in terms of temperature and water availability $\left(\mathrm{a}_{w}\right)$ which affect their scope for growth. A number of factors are important in reducing or eliminating such toxins from food and feed at key stages along supply chains (Table 4).

\section{Insert Table 4 here}

In considering the whole supply chain, it can be seen that there are several key stages where risk assessments and risk reduction strategies should be prioritised where fungal infections can lead to a build up of mycotoxins in raw materials, feed and food. These stages are critical as once grains, food or feed are contaminated then it is difficult if not impossible to economically remove these mycotoxins whether in the developed or developing world. The key risk reduction stages are:

- Pre-crop site assessment: as part of crop rotations, it is critical to evaluate sites in terms of the climatic conditions that may predispose the area to a higher risk of fungal growth. The risk rating would be further increased if previous crops and weeds were susceptible to fungal attack or have been previously infected and where surface trash is not buried through ploughing.

- Ear emergence to grain filling: this is a critical time to try and keep grains and seed heads clean for harvest; therefore, regular crop inspection especially in relation to weather conditions (warm and humid) are important with tactical use of fungicides where thresholds of infection are exceeded.

- Harvesting, processing and storage: harvesting early allied to rapid drying below $18 \%$ moisture content and cooling to $<15^{\circ} \mathrm{C}$ reduces the initial risks of fungal growth in stores. Further drying and cooling is advocated for longer term storage along with monitoring and pest controls. 
- Sampling and assessment: whether for food or feed, it is essential to sample and determine levels of mycotoxins in relation to legal limits and intended use. This is a major challenge as mycotoxins will not be evenly distributed through grains, feed and food. In the EU for example, guidance is given under Regulation 401/2006. Under this guidance food lots of $500 \mathrm{~kg}-1$ tonne require an aggregate sample of 10 incremental samples totalling $1 \mathrm{~kg}$ while lots of $>10$ tonnes to 20 tonnes requires 60 samples aggregated and weighing $6 \mathrm{~kg}$ (Food Standards Agency 2014).

- Processing: Thermal processing can denature some mycotoxins to more acceptable levels (see Table 4).

Other approaches to reducing the mycotoxin burden have been evaluated including mixing, decontamination through adsorbents, and chemical and biological treatments (Binder 2007, Wagacha and Muthomi 2008). The simplest approach, unless prohibited by legislation, would be to mix contaminated grains or feed with uncontaminated parts to reduce the average contamination level. However mycotoxin concentration in grains is not homogenous and so this is not recommended as it is ineffective. Blending batches containing,myctoxin in excess of a limitation established by regulations is not permissible (NebGuide 2003). The most commonly used method, however, is to include various binding agents or adsorbents which reduces mycotoxin uptake and distribution in animals; examples include aluminium silicates, clays and zeolitic minerals (Huwig et al. 2001). Other compounds may act as binding agents such as hydrated aluminosilicate which is particularly effective at binding with aflatoxins (Jouany 2007). However, no compounds were found to have binding capacity for a broad range of mycotoxins. For example, cholestyramine appears to be an effective binder for fumonisins and zearalenone in vitro while activated carbon was the only compound to bind with DON and nivalenol (Avanttaggiato et al. 2006). An alternative strategy is to manipulate existing gut microbes to further denature mycotoxins. For example, some rumen protozoa are known to degrade some mycotoxins (Schatzmayr et al. 2006), however they disappear if livestock are fed diets high in fermentable carbohydrates (Jouany 2007, Kiessling et al. 1984). Finally, potential bio-control agents have been considered where antitoxigenic strains of A. flavus and A. parasiticus have been introduced to soils to out-compete the toxin producing natural strains for these fungi (Ehrlich 2014). Overall corrective action of this nature is not to recommended.

\section{Conclusion}


Mycotoxins are a growing public concern and can affect human and animal health. Many are harmful to animals and can lead to poor performance and productivity or even fatalities; human exposure can also lead to illness and death. In order to reduce the impact of mycotoxins, it is necessary to try and prevent their occurrence in the first place and to have robust risk reduction strategies at the key stages in supply chains per. se. Every mycotoxin incident that occurs provides health authorities, regulators, food and farming industry with key lessons. It is essential that these lessons are learnt and considered to prevent and/or control future incidents. Comprehensive food safety programmes are needed that target both farmers and market supply chains. Given this insight into the relationships between food commodities, the environment and supply chains, it is important to consider how such knowledge could be applied to food safety programmes and the challenges facing developing and developed nations.

With regard to developing countries, mycotoxins are contaminating a large proportion of the world's food including maize, other cereals, groundnuts and other seeds. Many of these commodities are the staple diets of the population in developing countries in Africa, Asia and Latin America (Wild and Gong 2010). This is especially important for small-scale and subsistence farmers and their families where the bulk of their staple food is home grown, stored, prepared and consumed often in sub-optimal conditions. This means that there is little opportunity for public inspection and control as was the case in Kenya in 2004. Furthermore, many developing countries have poorly developed legislation and enforcement along with health services that are often stretched due to the ravages of poverty and malnutrition related illnesses. Indeed, mycotoxins are often not prioritised as a public health issue. At the same time agriculture is seen as an engine for development and governments are looking to export agricultural commodities as part of their development strategies, which is of limited value if products contain significant levels of mycotoxins. This leaves many developing countries with a dilemma of how to improve the health of local people whilst also increasing the export of agricultural commodities. To address this, the following strategies could be considered. Firstly engendering political will to address mycotoxin contamination and the capability to carry out tests for food and feed contamination. This is fundamental to protecting the country's population from mycotoxin exposure in the food and feed supply chain (Milicevic et al., 2015). Secondly building resilience in primary production with appropriate mycotoxin reduction strategies (Table 4) as part of agricultural extension by government agencies. This should include focus on the high risk stages of site selection and home saved seed and crop 
monitoring, especially at seed emergence, effective drying and storage. Thirdly, grain storage needs to be more robust. Significant contamination occurs in locally stored grains and pulses, especially if stored at home and in makeshift stores. The investment in locally available and well-designed public storage could contribute not only to safer staples but also to the provision of strategic local food reserves for communities. Public health programmes aimed at informing households about the risks of sourcing and storing grains and flours could be combined with food security and health messages. In stating this, there is an opportunity for joint promotion of safer food by health officers working with agricultural extension officers. There are also potential capacity building benefits from developed and developing public health officials working together as was shown in Kenya. In local, national and international value markets small-scale farmers are often seen as a source of new land and labour for formal marketing channels. Under these types of in-grower or out-grower schemes, the technical support and food safety systems are delivered to farmers through private sector agents and through the adoption of farm standards necessary for access to international markets. By including public extension in the model, wider benefits could accrue.

Alternatively, both public health regulation and private sector standards are well developed in most first world countries. As such, much of the concern over mycotoxins in developed countries is linked to global sourcing of raw materials for animal feeds and food processing. Although this is no reason for reducing the preventative programmes implemented in the UK to minimise mycotoxin contamination.

The combination of targeted legislation and efficient enforcement means that mycotoxin incidents in humans are relatively rare. This is further backed up by the risk reduction strategies built into farm assurance schemes and robust food industry standards underpinned by HACCP plans. However, as demand grows for raw materials for feed and food, then more is being sourced from developing countries. Thus, there is a need to ensure both risk reduction strategies and $\mathrm{HACCP}$ plans are extended to primary production and processing in extended global supply chains. Research institutions and agricultural departments of developed countries are continuously seeking to develop resistant cultivars. Development and careful selection of cultivars resistant to a broad range of mycotoxins and the sharing of resistant cultivars with producers from developing countries along with further mycotoxin mitigation strategies will help to ensure continued safe and sustainable production of cereal and pulses globally. 


\section{References}

639

640

641

642

643

644

645

646

647

648

649

650

651

652

653

654

655

656

657

658

659

660

661

662

663

664

665

666

667

668

669

670

Alm, T. (2003). The witch trials of Finnmark, Northern Norway, during the $17^{\text {th }}$ century:

Evidence of ergotism as a contributing factor. Economic Botany 57(3): 403-416.

Assuncao, R., Silva, M.J. and Alvito, P. 2016. Challenges in risk assessment of multiple mycotoxins in food. World Mycotoxin Journal 9(5): 791-811.

Avantaggiato, G., Solfrizzo, M. and Visconti, A. 2006. Recent advances on the use of adsorbent materials for detoxification of Fusarium mycotoxins. Food Additives and Contaminants 22(4): 379-388.

Azziz-Baumgartner E., Lindblade K., Gieseker K., Rogers H.S., Kieszak S., Njapau H., Schleicher R., McCoy L.F., Misore A., DeCock K., Rubin C., Slutsker L. and the Aflatoxin Investigative Group, 2005. Case control study of an acute aflatoxicosis outbreak, Kenya 2004. Environmental Health Perspective 113: 1779-1783.

Baines, R.N. 2009. Quality and safety standards in food supply chains. In: Mena, C. and Stevens, G. (eds.) Delivering performance in food supply chains. Woodhead Publishing, Cambridge, pp. 303-323.

Bennet, J. W. and Klich, M., 2003. Mycotoxin. Clinical Microbiology Reviews 16: 497-516.

Becroft, D.M.O., Webster, D.R., 1972. Aflatoxins and Reye's disease. Lancet 2: 117.

Belson, M.G., Schier, J.G. and Patel, M.M., 2005. Case definitions for chemical poisoning. Morbidity and Mortality Weekly Report 54(RR01): 1-24.

Berg, T., 2003. How to establish international limits for mycotoxins in food and feed. Food Control 14: 219-224.

Bennett, W.J. and Klinch, M., 2003. Mycotoxins. Clinical Microbiology Reviews 16: 497516.

Bhat, R.V., Ramakrishna, Y., Beedu. S.R. and Munshi, K.L., 1989. Outbreak of trichothecene mycotoxicosis associated with consumption of mould-damaged wheat products in Kashmir Valley, India. Lancet 333(8628): 35-37.

Bhat, R.V. and Krishnamachari, K.A.V.R., 1977. Follow-up study of aflatoxic hepatitis in parts of Western India. Indian Journal of Medical Research 66(1): 55-58.

Binder, E.M., 2007. Managing the risk of mycotoxins in modern feed production. Animal Feed Science and Technology 133: 149-166.

Binder, E.M., Tan, L.M., Chin, L.J., Handl, J. and Richard, J., 2007. Worldwide occurrence of mycotoxins in commodities, feeds and feed ingredients. Animal Feed Science and Technology 137: 265-282. 
671 Boudra, H., Barnouin, J., Dragacci, S. and Morgavi, D.P., 2007. Aflatoxin M1 and ochratoxin

672

673

674

675

676

677

678

679

680

681

682

683

684

685

686

687

688

689

690

691

692

693

694

695

696

697

698

699

700

701

702

703

A in raw milk from French dairy herds. Journal of Dairy Science 90: 3197-3201.

Bryden, W.L., 2007. Mycotoxins in the food chain: human health implications. Asia Pacific Journal of Clinical Nutrition 16 (Suppl. 1): 95-101.

CAC, Codex Alimentarius Commission, no date. General standard for contaminants and toxins in food and feed (Codex Stan 193-1995) Adopted in 1995. Revised in 1997, 2006, 2008, 2009. Amendment 2010, 2012, 2013, 2014.

Caporael, L.R., 1976. Ergotism: The Satan loosed in Salem? Science 192: 21-26.

CAST, Council for Agricultural Science and Technology, 2003. Mycotoxins: Risks in plant, animal and human systems. Report No 139, Council for Agricultural Science and Technology, Ames, Iowa, USA.

CDC, Centers for Disease Control and Prevention, 1999. Outbreaks of gastrointestinal illness of unknown etiology associated with eating burritos. Morbidity and Mortality Weekly Report 48(10):210-213.

CDC, Centers for Disease Control and Prevention, 2004. Outbreak of aflatoxin poisoning Eastern and Central Provinces, Kenya, January-July 2004. Available at: http://www.cdc.gov/mmwr/preview/mmwrhtml/mm5334a4.htm

Coffey, R., Cummins, E. and Ward, S., 2009. Exposure assessment of mycotoxins in dairy milk. Food Control 20: 239-249.

CONTAM, EFSA Panel on Contaminants in the Food Chain, 2014. Scientific Opinion on the risks for human and animal health related to the presence of modified forms of certain mycotoxins in food and feed. EFSA Journal 12(12): 3916.

Cotty, P. J. and Jaime-Garcia, R. 2007. Influences of climate on aflatoxin producing fungi and aflatoxin contamination. International Journal of Food Microbiology 119(1-2): 109115.

Dellafiora, L. and Dall'Asta, C. (2016). Masked mycotoxins: An emerging issue that makes negotiable what is ordinary. Food Chemistry 213: 534-535.

Dellafiora, L. and Dall'Asta, C. (2017). Forthcoming challenges in mycotoxins toxicology research for safer food - A need for multi-omics approach. Toxins 9(2): doi:10.3390/toxins 9010018

Dellafiora, L., Dall'Asta, C. and Cozzini, P., 2015. Ergot alkaloids: From witchcraft till in silico analysis. Multi-receptor analysis of ergotamine metabolites. Toxicology Reports 2: 535-545. 
Dellafiora, L., Galaverna, G., Righi, F., Cozzini, P. and Dall'Asta, C., 2017. Assessing the hydrolytic fate of the masked mycotoxin zearalenone-14-glucoside - A warning light for the need to look at the "maskedome". Food and Chemical Toxicology 99: 9-16.

De Boevre, M., Jacxsens, L., Lachat, C., Eeckhout, M., Di Mavungu, J.D., Audenaert, K., et al., 2013. Human exposure to mycotoxins and their masked forms through cereal-based foods in Belgium. Toxicology Letters 218(3): 281-292.

De Saeger, S. and van Egmond, H., 2012. Special issue: Masked mycotoxins. World Mycotoxin Journal 5(3): 203-206.

de Vries, H.R., Maxwell, S.M. and Hendrickse, R.G., 1990. Aflatoxin excretion in children with kwashiorkor or marasmic kwashiorkor - a clinical investigation. Mycopathologia 110: $1-9$.

Dvorackova, I., Kusak, V., Vesely, D., Vesela, J. and Nesnidal, P., 1997. Aflatoxin and encephalopathy with fatty degeneration of viscera (Reye). Annales de la nutrition et de L'alimentation, 31: 977-990.

Dvorackova, I., Vesely, D. and Kusak, V., 1979. Aflatoxins as pathological agents in young children. CÏ eskoslovenska pediatrie 34: 80-83.

Eadie, M. J., 2003. Convulsive ergotism: epidemics of the serotonin syndrome? Lancet Neurology 2(7): 429-434.

EC, 2011. BIOCOP Report summary. Available at: http://cordis.europa.eu/result/rcn/52964_en.html [Accessed 20 June 2017]

EC No. 1881/2006 (2006). Commission Regulation (EC) No. 1881/2006 of 19 December 2006 setting maximum levels for certain contaminants in foodstuffs. Available at: http://eurlex.europa.eu/LexUriServ/LexUriServ.do?uri=CONSLEG:2006R1881:20100701:EN:PD F [Accessed 24 September 2016]

EU Science Hub, 2016. European Union reference laboratory for mycotoxins. Available at: https://ec.europa.eu/jrc/en/network-bureau/european-union-reference-laboratorymycotoxins [Accessed 20 June 2017]

Ehrlich, K.C., 2014. Non-aflatoxigenic Aspergillus flavus to prevent aflatoxin contamination in crops: advantages and limitations. Frontiers in Microbiology 5(50): 25-33. 
Etzel, R.A., 2006. What the primary care pediatrician should know about syndromes associated with exposures to mycotoxins. Current Problems in Pediatric and Adolescent Health Care 36: 282-305.

FAO, Food and Agriculture Organisation, 2000. Preamble and Annexes. Codex General Standard for Contaminants and Toxins in Food. CODEX-STAN 193-1995 (Rev 1 1997). Rome.

FAO, Food and Agriculture Organisation, 2001. Chapter 1: An Introduction to Mycotoxins. In: Food and Agriculture Organisation (ed.) Manual on the application of the HACCP system in mycotoxin prevention and control. FAO UN, Rome. Available at: ftp://ftp.fao.org/docrep/fao/005/y1390e/y1390e00.pdf

FAO, Food and Agriculture Organisation, 2004. Worldwide regulations for mycotoxins in food and feed in 2003. Available at: http://www.fao.org/docrep/007/y5499e/y5499e06.htm [Accessed 20 June 2017].

Food Standards Agency, 2014. Mycotoxin sampling guidance. Reviewed December 2014. Available at: https://www.food.gov.uk/sites/default/files/mycotoxins-samplingguidance.pdf

Gawalko, E., Garrett, R.G., Warkentin, T., Wang, N. and Richter, A., 2009. Trace elements in Canadian field peas: a grain safety assurance perspective. Food Additives and Contaminants 26(7): 1002-1012.

Gratz, S.W., Dinesh, R., Yoshinari, T., Holtrop, G., Richardson, A.J., Duncam, G. et al., 2017. Masked trichothecene and zearalenone mycotoxins withstand digestion and absorption in the upper GI tract but are efficiently hydrolysed by human gut microbiota in vitro. Molecular Nutrition and Food Research 61(4): 1600680.

Grenier, B. and Oswald, I. 2011. Mycotoxin co-contamination of food and feed: metaanalysis of publications describing toxicological interactions. World Mycotoxin Journal 4(3): 285-313.

Hogan, G.R., Ryan, N.J. and Hayes, A.W., 1978. Aflatoxin B1 and Reye's syndrome. Lancet. 311(8063): 561.

Hove, M., De Boevre, M., Lachat, C., Jacxsens, L., Nyanga, L. K. and De Saeger, S. (2016). Occurrence and risk assessment of mycotoxins in subsistence farmed maize from Zimbabwe. Food Control 69: 36-44.

Hulvova, H., Galuszka, P., Frebortova, J. and Frebort, I., 2013. Parasitic fungus Claviceps as a source for biotechnological production of ergot alkaloids. Biotechnology Advances 31(1): 79-89. 
Huwig, A., Freimund, S., Kappeli, O. and Dutler, H., 2001. Mycotoxin detoxification of animal feed by different adsorbents. Toxicology Letters 122(2): 179-188.

Jacxsens, L., Yogendrarajaha, P. and De Meylenaer, B., 2016. Risk assessment of mycotoxins and predictive mycology in Sri Lankan spices: Chilli and pepper. Procedia Food Science 6: 326-330.

Jarvis, B.B., 2002. Chemistry and toxicology of molds isolated from water-damaged buildings. Mycotoxins and Food safety. Springer, U.S., pp. 43-52.

Jouany, J.P., 2007. Methods for preventing, decontaminating and minimizing the toxicity of mycotoxins in feeds. Animal Feed Science and Technology 137: 342-362.

Kenzhebayeza, S., Turasheva, S., Doktyrbay, G., Buerstmayr, H., Atabayeva, S. and Alybaeva, R., 2014. Screening of mutant wheat lines to resistance for Fusarium head blight and using SSR markers for detecting DNA polymorphism. IERI Procedia 8: 66-76.

Kiessling, K.H., Pettersson, H., Sandholm, K. and Olsen, M. 1984. Metabolism of aflatoxin, ochratoxin, zearalenone, and three trichothecenes by intact rumen fluid, rumen protozoa and rumen bacteria. Applied and Environmental Microbiology 47(5): 1070-1073.

King, B., 1979. Outbreak of ergotism in Wollo, Ethiopia. Lancet 313(8131): 1411.

Krishnamachari, K.A. and Bhat, R.V., 1976. Poisoning of ergoty bajra (pearl millet) in man. Indian Journal of Medical Research 64: 1624-1628.

Krishnamachari, K.A., Bhat, R.V., Nagarajan, V. and Tilak, T.B., 1975. Hepatitis due to aflatoxicosis. An outbreak in West India. Lancet 305(7915): 1061-1063.

Kuiper-Goodman, T. 1999. Approaches to the risk analysis of mycotoxins in the food supply. Food Nutrition and Agriculture: 10-16.

Kuiper-Goodman, T. 2004. Risk assessment and risk management of mycotoxins in food. Mycotoxins in food: detection and control. Boca Raton: CRC Press, pp. 1-31.

Lee, H. J. and Ryu, D. 2017. Worldwide occurrence of mycotoxins in cereals and cerealderived food products: Public health perspectives of their co-occurrence. Journal of Agricultural and Food Chemistry DOI 10.1021/acs.jafc.6b04847

Lee, M. R., 2009. The history of ergot of rye (Claviceps purpurea) I: from antiquity to 1900. JR Coll Physicians Edinb 39: 179-184.

Lerda, D., 2011. Mycotoxins factsheet. $4^{\text {th }}$ edition. Available at:

$$
\text { https://ec.europa.eu/jrc/sites/default/files/Factsheet\%20Mycotoxins_2.pdf }
$$

Lewis, L., Onsongo, M., Njapau, H., Schurz-Rogers, H., Luber, G., Kieszak, S. et al., 2005. Aflatoxin contamination of commercial maize products during an outbreak of acute 
aflatoxicosis in Eastern and Central Kenya. Environmental Health Perspectives 113(12): 1763-1767.

Luo, X. Y., 1988a. Fusarium toxins contamination of cereals in China. In: Aibara, K., Kumagai, S., Ohtsubo, K. and Yoshizawa, T. (eds.) Proceedings of the Seventh International IUPAC Symposium on Mycotoxins and Phycotoxins, Tokyo, 16-19 August 1988. Tokyo, Japanese Association of Mycotoxicology, pp. 97-98.

Luo X., 1988b. Food poisoning associated with Fusarium toxins. In: Aibara, K., Kumagai, S., Ohtsubo, K. and Yoshizawa, T. (eds.) Proceedings of the Seventh International IUPAC Symposium on Mycotoxins and Phycotoxins, Tokyo, 16-19 August 1988. Tokyo, Japanese Association of Mycotoxicology, pp 93.

MacDonald, D.J., 2005. The HACCP concept and its application in primary production. In: Mead, G.C. (ed.) Food safety control in the poultry industry. Woodhead Publishing, Cambridge, pp. 237-254.

Maestroni, B. and Cannavan, A. 2011. Chapter 1 - Sampling strategies to control mycotoxins. In, S. De Saeger (Ed). Determining Mycotoxins and Mycotoxigenic Fungi in Food and Feed. Cambridge, UK: Woodhead Publishing, pp. 3-36.

Mannon, J. and Johnson, E., 1985. Fungi down on the farm. New Scientist 105: 12-16.

Marr, J.S. and Malloy, C.D., 1996. An epidemiologic analysis of the ten plagues of Egypt. Caduceus 12: 7-24.

Marroquin-Cardona, A. G., Johnson, N. M., Phillips, T. D. and Hayes, A. W. 2014. Mycotoxins in a changing global environment - A review. Food and Chemical Toxicology 69: 220-230.

Milicevic, D., Nesic, K. and Jaksic, S. 2015. Mycotoxin contamination of the food supply chain - Implications for One Health Programme. Procedia Food Science 5: 187-190.

Mitchell, N.J., Chen, C., Palumbo, J.D., Bianchini, A. Cappozzo, J., Stratton, J. et al., 2017. A risk assessment of dietary Ochratoxin A in the United States. Food and Chemical Toxicology 200: 265-273.

MoniQA Association, 2017. Brief description of the MoniQA NoE. Available at: http://www.moniqa.org/moniqa_noe/overview [Accessed 20 June 2017]

Mulac, D. and Humpf, H.-U., 2011. Cytotoxicity and accumulation of ergot alkaloids in human primary cells. Toxicology 282: 112-121.

Muture, B. N. and Ogana, G. 2005. Aflatoxin levels in maize and maize products during the 2004 food poisoning outbreak in eastern province of Kenya. East African Medical Journal 82(6): 275-279. 
NebGuide. 2003. Use of feed contaminated with fungal (mold) toxins (mycotoxins).

Nebraska Extension. Available at: http://extensionpublications.unl.edu/assets/html/g1514/build/g1514.htm [Accessed 25 September 2016].

Ngindu, A., Kenya, P.R., Ocheng, D.M., Omondi, T.N., Ngare, W., Gatei, D. et al., 1982. Outbreak of acute hepatitis caused by aflatoxin poisoning in Kenya. Lancet, 319(8285): 1346-1348.

Oyedele, O.A., Ezekiel, C.N., Sulyok, M., Adetunji, M.C., Warth, B., Atanda, O.O et al., 2017. Mycotoxin risk assessment for consumers of groundnut in domestic markets in Nigeria. International Journal of Food Microbiology 251: 24-32.

Oyelami, O.A., Maxwell, S.M. and Adelusola, K.A., 1995. Aflatoxins in the autopsy brain tissue of children in Nigeria. Mycopathologia 132: 35-38.

Oyelami, O.A., Maxwell, S.M., Adelusola, K.A., Aladekoma, T.A. and Oyelese, A.O., 1997. Aflatoxins in lungs of children with Kwashiorkor and children with miscellaneous diseases in Nigeria. Journal of Toxicology and Environmental Health 51: 623-628.

Patriarca, A. and Pinto, V. F., 2017. Prevalence of mycotoxins in foods and decontamination. Current Opinion in Food Science 14: 50-60.

Peraica, M., Radic, B., Lucic, A. and Pavlovic, M., 1999. Toxic effects of mycotoxins in humans. Bulletin of the World Health Organization 77(9): 754-966

Probst, C., Njapau, H. and Cotty, P. J. 2007. Outbreak of an acute aflatoxicosis in Kenya in 2004: Identification of the causal agent. Applied and Environmental Microbiology 73(8): 2370-2376.

Probst, C., Schulthess, F. and Cotty, P. J., 2010. Impact of Aspergillus section Flavi community structure on the development of lethal levels of aflatoxins in Kenyan maize (Zea mays). Journal of Applied Microbiology 108(2): 6000-610.

Quiles, J. M., Saladino, F., Manes, J., Fernandez-Franzon, M. and Meca, G. 2016. Occurrence of mycotoxins in refrigerated pizza dough and risk assessment of exposure for the Spanish population. Food and Chemical Toxicology 94: 19-24.

Raiola, A., Tenore, G. C., Manyes, L., Meca, G. and Ritieni, A., 2015. Risk analysis of main mycotoxins occurring in food for children: An overview. Food and Chemical Toxicology 84: 169-180.

Ramakrishna, Y., Bhat, R.V. and Ravindranath, V., 1989. Production of deoxynivalenol by Fusarium isolates from samples of wheat associated with a human mycotoxicosis 
outbreak and from sorghum cultivars. Applied and Environmental Microbiology 55: 2619-2620.

RASFF, Rapid Alert System for Food and Feed, 2015. RASFF for safer food — The Rapid Alert System for Food and Feed - 2014 annual report. Available at: http://ec.europa.eu/food/safety/rasff/docs/rasff_annual_report_2014.pdf

Rice, L.G. and Ross, F.B., 1994. Methods for detection and quantitation of fumonisins in corn, cereal products and animal excreta. Journal of Food Protection 57: 36-40.

Richard, J.L. and Thurston, J.R., 1986. Diagnosis of mycotoxicoses. Martinus Nijhoff, Boston.

Richard, J.L., 2003. Mycotoxins and human disease. In: Anaissie, E.J., McGinnis, M.R., Pfaller, M.A. (eds.) Clinical Mycology. Churchill Livingstone, New York, pp. 589-598.

Richard, J.L., 2007. Some major mycotoxins and their mycotoxicoses - An overview. International Journal of Food Microbiology 119: 3-10.

Riley, R.T., 1998. Mechanistic interactions of mycotoxins: theoretical considerations. In: Sinah, K.K. and Bhatangagar, D. (eds.) Mycotoxins in agriculture and food safety. Marcel Dekker Inc., Basel, New York, pp. 227-254.

Ryan, N.J., Hogan, G.R., Hayes, A.W., Unger, P.D. and Siraj, P.D., 1979. Aflatoxin B1: its role in the etiology of Reye's syndrome. Paediatrics 64: 71-75.

Saladino, F., Quiles, J.M., Manes, J., Fernandez-Franzon, M., Luciano, F. and Meca, G. 2017. Dietary exposure to mycotoxins through the consumption of commercial bread loaf in Valencia, Spain. LWT - Food Science and Technology 75: 697-701.

Schatzmayr, G., Zehner, F., Taubel, M., Schatzmayr, D., Klimitsch, A., Loibner, A. P. and Binder, E.M. 2006. Microbiologicals for deactivating mycotoxins. Molecular Nutrition and Food Research 50(6): 543-551.

Schiff, P. L., 2006. Ergot and its alkaloids. American Journal of Pharmaceutical Education 70(5): 98

Serck-Hanssen A., 1970. Aflatoxin-induced fatal hepatitis? A case report from Uganda. Archives of Environmental Health 20: 729-731.

Shank, R.C., Bourgeois, C.H., Keschamras, N. and Chandavimol, P., 1971. Aflatoxins in autopsy specimens from Thai children with an acute disease of unknown aetiology. Food and Cosmetics Toxicology 9: 501-507.

Shephard, G. S. 2007. Impact of mycotoxins on human health in developing countries. Food Additives \& Contaminants: Part A 25(2): 146-151. 
Sherif, S.O., Salama, E.E. and Abedl-Wahhab, M.A. 2009. Mycotoxins and child health: The need for health risk assessment. International Journal of Hygiene and Environmental Health 212: 347-368.

Soon, J.M., Manning, L., Davies, W.P. and Baines, R., 2012. Fresh produce-associated outbreaks: a call for HACCP on farms? British Food Journal 114: 553-597.

Steinberg, E.B., Henderson, A., Karpati, A., Hoekstra, M., Marano, N., Souza, J.M. et al., 2006. Mysterious outbreaks of gastrointestinal illness associated with burritos supplied through school lunch programs. Journal of Food Protection 69(7): 1690-1698.

Streit, E., Schatzmayr, G., Tassis, P., Tzika, E., Marin, D., Taranu, I., et al. 2012. Current situation of mycotoxin contamination and co-occurrence in animal feed - focus on Europe. Toxins 4(10): 788-809.

Sundheim, L., Lillegaard, I.T., Fæste, C.K., Brantsæter, A.-L., Brodal. G. and Eriksen, G.S. 2017. Deoxynivalenol exposure in Norway, risk assessments for different human age groups. Toxins 9(2): 46.

Tandon, B.N., Krishnamurthy, L., Koshy, A., Tandon, H. D., Ramalingswami, V., Bhandari, J.R. et al., 1977. Study of an epidemic of jaundice, presumably due to toxic hepatitis, in Northwest India. Gastroenterology 72: 488-494.

US FDA 2000. Guidance for industry: Action levels for poisonous or deleterious substances in food and animal feed. Available at: http://www.fda.gov/Food/GuidanceRegulation/GuidanceDocumentsRegulatoryInformatio n/ChemicalContaminantsMetalsNaturalToxinsPesticides/ucm077969.htm [Accessed 24 September 2016]

van Dijk, H., Houghton, J., van Kleef, E., van der Lans, I., Rowe, G. and Frewer, L., 2008. Consumer responses to communication about food risk management. Appetite 50(2-3): 340-352.

van Egmond, H.P., Schothorst, R.C. and Jonker, M.A. 2007. Regulations relating to mycotoxins in food. Analytical and Bioanalytical Chemistry 389(1): 147-157.

Wagacha, J.M. and Muthomi, J.W., 2008. Mycotoxin problem in Africa: Current status, implications for food safety and health and possible management strategies. International Journal of Microbiology 124: 1-12.

Willis, R.M., Mulvihill, J.J. and Hoofnagle, J.H., 1980. Attempted suicide with purified aflatoxin. Lancet 315(8179): 1198-1199.

Wild, C.P. and Gong, Y.Y., 2010. Mycotoxins and human disease: a largely ignored global health issue. Carcinogenesis 31: 71-82. 
937 Woolf, A., 2000. Witchcraft or mycotoxin? The Salem witch trials. Journal of Toxicology: Clinical Toxicology 938 38(4): 457-460.

939 Wu, F., 2004. Mycotoxin risk assessment for the purpose of setting international regulatory standards,

940 Environmental Science \& Technology 38(15): 4049-4055.

941

942 
Table 1 Human diseases associated with cereals and pulses contaminated with mycotoxins and indicative health effects in humans and animals (Adapted from Binder 2007, Bryden 2007, CAST 2003, Etzel 2006, Riley 1998, Sherif et al. 2009)

\begin{tabular}{|c|c|c|c|c|}
\hline $\begin{array}{l}\text { Classic Disease } \\
\text { Association }\end{array}$ & $\begin{array}{l}\text { Typical } \\
\text { Food } \\
\text { Sources }\end{array}$ & $\begin{array}{l}\text { Fungal Group } \\
\text { or species }\end{array}$ & $\begin{array}{l}\text { Associated } \\
\text { Mycotoxins }\end{array}$ & $\begin{array}{l}\text { Health Effects Associated with } \\
\text { Mycotoxins }\end{array}$ \\
\hline Akakabio-byo & $\begin{array}{l}\text { wheat, } \\
\text { barley, } \\
\text { oats, rice }\end{array}$ & Fusarium spp. & $\begin{array}{l}\text { Fusarium } \\
\text { toxins }\end{array}$ & \multirow{4}{*}{$\begin{array}{l}\text { Vomiting, central nervous } \\
\text { system damage, haemorrhaging } \\
\text { cell necrosis associated with } \\
\text { inhibition of protein synthesis } \\
\text { and elevated } \mathrm{CA}^{2+} \text { initiating } \\
\text { endonuclease activation - cell } \\
\text { apoptosis }\end{array}$} \\
\hline $\begin{array}{l}\text { Alimentary toxic } \\
\text { aleukia } \\
\text { (ATA or septic } \\
\text { angina) }\end{array}$ & $\begin{array}{l}\text { cereal } \\
\text { grains } \\
\text { (toxic } \\
\text { bread) } \\
\end{array}$ & Fusarium spp. & T-2 Toxin & \\
\hline $\begin{array}{l}\text { Kashin Beck disease, } \\
\text { Urov disease }\end{array}$ & $\begin{array}{l}\text { cereal } \\
\text { grains }\end{array}$ & Fusarium spp. & $\begin{array}{l}\text { T-2 Toxin but } \\
\text { not proven }\end{array}$ & \\
\hline Onyalai & millet & $\begin{array}{l}\text { Phoma } \\
\text { sorghina }\end{array}$ & $\begin{array}{l}\text { Aetiology } \\
\text { unknown } \\
\text { possibly } \\
\text { Fusarium } \\
\text { toxins }\end{array}$ & \\
\hline Balkan nephropathy & $\begin{array}{l}\text { cereal } \\
\text { grains }\end{array}$ & $\begin{array}{l}\text { Penicillium } \\
\text { spp., } \\
\text { Aspergillus spp. }\end{array}$ & $\begin{array}{l}\text { Ochratoxin A } \\
\text { - not proven }\end{array}$ & \multirow{2}{*}{$\begin{array}{l}\text { Renal cancer. Reduced immune } \\
\text { system. Reduced } \\
\text { glyconeogenesis - cell death. } \\
\text { Inhibition of protein synthesis - } \\
\text { cell apoptosis. Disruption of Ca } \\
\text { transport - cell deregulation and } \\
\text { apoptosis. }\end{array}$} \\
\hline Cardiac beriberi & rice & $\begin{array}{l}\text { Aspergillus } \\
\text { spp., } \\
\text { Penicillium spp. }\end{array}$ & Not specified & \\
\hline Dendrodochiotoxicosis & $\begin{array}{l}\text { fodder } \\
\text { (skin } \\
\text { contact, } \\
\text { inhaled } \\
\text { fodder } \\
\text { particles) }\end{array}$ & $\begin{array}{l}\text { Dendrodochium } \\
\text { toxicum }\end{array}$ & $\begin{array}{l}\text { Possibly } \\
\text { Verrucarin A }\end{array}$ & $\begin{array}{l}\text { Oral lesions, diarrhea, } \\
\text { hemorrhagic gastroenterocolitis, } \\
\text { oedema. Inhibits protein } \\
\text { synthesis in cells - cell apoptosis }\end{array}$ \\
\hline Ergotism & $\begin{array}{l}\text { rye, cereal } \\
\text { grains }\end{array}$ & $\begin{array}{l}\text { Claviceps } \\
\text { purpurea }\end{array}$ & $\begin{array}{l}\text { Ergotamines } \\
\text { - alkaloids } \\
\text { produced by } \\
\text { plants in } \\
\text { response to } \\
\text { infection }\end{array}$ & $\begin{array}{l}\text { Nervous disorders (itching skin } \\
\text { and nervous convulsions) and } \\
\text { gangrene due to vascular } \\
\text { restrictions. }\end{array}$ \\
\hline Oesophageal tumors & corn & $\begin{array}{l}\text { Fusarium } \\
\text { verticillioides }\end{array}$ & Fumonisins & $\begin{array}{l}\text { Vomiting, neural tube defects, } \\
\text { pulmonary oedema and } \\
\text { oesophageal cancer. Disrupted } \\
\text { lipid metabolism - cell } \\
\text { deregulation - cell apoptosis }\end{array}$ \\
\hline $\begin{array}{l}\text { Hepatocarcinoma } \\
\text { (acute } \\
\text { aflatoxicosis) }\end{array}$ & $\begin{array}{l}\text { cereal } \\
\text { grains, } \\
\text { peanuts }\end{array}$ & $\begin{array}{l}\text { Aspergillus } \\
\text { flavus, } \\
\text { A. parasiticus }\end{array}$ & $\begin{array}{l}\text { Aflatoxins } B_{1}, \\
B_{2}, G_{1}, G_{2}\end{array}$ & \multirow{3}{*}{$\begin{array}{l}\text { Vomiting, hepatitis, liver disease } \\
\text { and cancer (DNA modification - } \\
\text { cell deregulation - cell } \\
\text { death/transformation) }\end{array}$} \\
\hline Reye's syndrome & $\begin{array}{l}\text { Cereal } \\
\text { grains }\end{array}$ & Aspergillus spp. & $\begin{array}{l}\text { Aflatoxins } \\
\text { may play a } \\
\text { part in some } \\
\text { cases }\end{array}$ & \\
\hline Kwashiorkor & $\begin{array}{l}\text { cereal } \\
\text { grains }\end{array}$ & $\begin{array}{l}\text { Aspergillus } \\
\text { flavus, } \\
\text { A. parasiticus }\end{array}$ & $\begin{array}{l}\text { Aflatoxins } \\
\text { but not a } \\
\text { proven link }\end{array}$ & \\
\hline Stachybotryotoxicosis & $\begin{array}{l}\text { hay, cereal } \\
\text { grains, } \\
\text { fodder }\end{array}$ & $\begin{array}{l}\text { Stachybotrys } \\
\text { chartarum }\end{array}$ & $\begin{array}{l}\text { Trichothecene } \\
\text {-satratoxins }\end{array}$ & $\begin{array}{l}\text { Rashes, especially in areas } \\
\text { subject to perspiration, } \\
\text { dermatitis, pain and }\end{array}$ \\
\hline
\end{tabular}




\begin{tabular}{|l|l|l|l|l|}
\hline $\begin{array}{l}\text { (skin } \\
\text { contact, } \\
\text { inhaled hay } \\
\text { dust) }\end{array}$ & & $\begin{array}{l}\text { (L, D, F, G } \\
\text { and H) }\end{array}$ & $\begin{array}{l}\text { inflammation of the mucous } \\
\text { membranes, a burning sensation } \\
\text { of the eyes and nasal passages, } \\
\text { tightness of the chest, cough, } \\
\text { bloody rhinitis, fever, headache, } \\
\text { and fatigue. }\end{array}$ \\
\hline
\end{tabular}


Table 2 Examples of mycotoxicoses in terms of people affected (and deaths), food sources and toxins identified (Adapted from Peraica et al. 1999, Wild and Gong 2010)

\begin{tabular}{|c|c|c|c|c|}
\hline Location & $\begin{array}{c}\text { Affected } \\
\text { (Fatalities) }\end{array}$ & Source & Toxin & References \\
\hline \multirow{5}{*}{ India } & 397 (106) & Maize & Aflatoxin unspecified & $\begin{array}{l}\text { Krishnamachari et al. (1975) } \\
\text { Bhat and Krishnamachari (1977) }\end{array}$ \\
\hline & $994(97)$ & Maize & Aflatoxin $\mathrm{B}_{1}$ & Tandon et al. (1977) \\
\hline & $397(106)$ & Maize & $\begin{array}{l}\text { Aflatoxins not } \\
\text { specified }\end{array}$ & Krishnamachari et al. (1975) \\
\hline & $\begin{array}{c}78 \text { (not } \\
\text { available) }\end{array}$ & Pearl millet & Clavine alkaloids & Krishnamachari and Bhat (1976) \\
\hline & $97(0)$ & Wheat & $\begin{array}{l}\text { Nivalenol, DON, T-2 } \\
\text { Toxin }\end{array}$ & $\begin{array}{l}\text { Bhat et al. (1989) } \\
\text { Ramakrishna et al. (1989) }\end{array}$ \\
\hline \multirow{3}{*}{ Kenya } & $20(12)$ & Maize & Aflatoxin $\mathrm{B}_{1}$ and $\mathrm{B}_{2}$ & Ngindu et al. (1982) \\
\hline & $12(5)$ & Kwashiorkor & $\begin{array}{l}\text { Aflatoxin } B_{1} \\
\text { few } B_{2}, M_{1} \& M_{2}\end{array}$ & de Vries et al. (1990) \\
\hline & $317(125)$ & Maize & $\begin{array}{l}\text { Aflatoxins not } \\
\text { specified }\end{array}$ & Azziz-Baumgartner et al. (2005) \\
\hline \multirow[b]{2}{*}{ USA } & $1(0)$ & $\begin{array}{l}\text { Purified } \\
\text { Aflatoxin }\end{array}$ & Aflatoxin $\mathrm{B}_{1}$ & Willis et al. (1980) \\
\hline & $\begin{array}{l}22(22) \\
10(10)\end{array}$ & $\begin{array}{l}\text { Reye } \\
\text { Syndrome } \\
\text { Control }\end{array}$ & $\begin{array}{l}\text { Aflatoxin } B_{1} \\
\text { Aflatoxin } B_{1}\end{array}$ & $\begin{array}{l}\text { Hogan et al. }(1978) \\
\text { Ryan et al. }(1979) \\
\text { Ryan et al. }(1979)\end{array}$ \\
\hline Czechoslovakia & $\begin{array}{l}27(27) \\
25(25)\end{array}$ & $\begin{array}{l}\text { Reye } \\
\text { Syndrome } \\
\text { Non Reye } \\
\text { Syndrome }\end{array}$ & $\begin{array}{l}\text { Aflatoxin } \mathrm{B}_{1} \text { and } \mathrm{M}_{1} \\
\text { Aflatoxin } \mathrm{B} 1 \text { and } \mathrm{M}_{1}\end{array}$ & $\begin{array}{l}\text { Dvorackova et al. (1977) } \\
\text { Dvorackova et al. (1979) }\end{array}$ \\
\hline New Zealand & $2(2)$ & Rye Syndrome & Aflatoxin $\mathrm{B}_{1}$ & Becroft and Webster (1972) \\
\hline Uganda & $1(1)$ & Cassava & Aflatoxin unspecified & Serck-Hanssen (1970) \\
\hline Thailand & $\begin{array}{l}23(23) \\
15(15)\end{array}$ & $\begin{array}{l}\text { Reye } \\
\text { Syndrome } \\
\text { Control }\end{array}$ & $\begin{array}{l}\text { Aflatoxin } \mathrm{B}_{1}, \mathrm{~B}_{2} \text { and } \\
\mathrm{M}_{1} \\
\text { Aflatoxin } \mathrm{B}_{1} \text { and } \mathrm{B}_{2}\end{array}$ & Shank et al. (1971) \\
\hline Nigeria & $\begin{array}{l}38(38) \\
39(39) \\
\end{array}$ & $\begin{array}{l}\text { Kwashiorkor } \\
\text { Controls }\end{array}$ & $\begin{array}{l}\mathrm{B}_{1}, \mathrm{~B}_{2}, \mathrm{G}_{1}, \mathrm{G}_{2}, \mathrm{M}_{1}, \mathrm{M}_{2} \\
\text { in both groups }\end{array}$ & $\begin{array}{l}\text { Oyelami et al. }(1995) \\
\text { Oyelami et al. }(1997)\end{array}$ \\
\hline Ethiopia & $140(48)$ & Grain & $\begin{array}{l}\text { Ergotamine- } \\
\text { ergocristine alkaloid }\end{array}$ & King (1979) \\
\hline China 1984-85 & $463(0)$ & Maize, Wheat & DON, Zearalenone & Luo (1988b) \\
\hline
\end{tabular}


No 1881/2006, Richard 2007, US FDA 2000)

\begin{tabular}{|c|c|c|c|}
\hline \multicolumn{2}{|c|}{ US } & \multicolumn{2}{|c|}{$\mathbf{E U}$} \\
\hline $\begin{array}{l}\text { Commodity and } \\
\text { intended use }\end{array}$ & $\begin{array}{c}\text { Maximum levels } \mu \mathrm{g} / \mathrm{kg} \\
\text { (aflatoxin type) }\end{array}$ & $\begin{array}{l}\text { Commodity and } \\
\text { intended use }\end{array}$ & $\begin{array}{c}\text { Maximum levels } \mu \mathrm{g} / \mathrm{kg} \\
\text { (aflatoxin type) }\end{array}$ \\
\hline $\begin{array}{l}\text { All products except milk } \\
\text { for human consumption }\end{array}$ & 20 & $\begin{array}{l}\text { Groundnuts (peanuts), } \\
\text { dried fruit and processed } \\
\text { products thereof for } \\
\text { direct human } \\
\text { consumption }\end{array}$ & $\begin{array}{l}2.0(\mathrm{~B} 1) \\
4.0\left(\text { Sum of } \mathrm{B}_{1}, \mathrm{~B}_{2}, \mathrm{G}_{1}\right. \\
\left.\text { and } \mathrm{G}_{2}\right)\end{array}$ \\
\hline & & $\begin{array}{l}\text { Almonds, pistachios and } \\
\text { apricot kernels intended } \\
\text { for direct human } \\
\text { consumption }\end{array}$ & $\begin{array}{l}8.0(\mathrm{~B} 1) \\
10.0\left(\mathrm{Sum} \text { of } \mathrm{B}_{1}, \mathrm{~B}_{2}, \mathrm{G}_{1}\right. \\
\left.\text { and } \mathrm{G}_{2}\right)\end{array}$ \\
\hline & & $\begin{array}{l}\text { Hazelnuts and Brazil } \\
\text { nuts intended for direct } \\
\text { human consumption }\end{array}$ & $\begin{array}{l}5.0(\mathrm{~B} 1) \\
10.0\left(\mathrm{Sum} \text { of } \mathrm{B}_{1}, \mathrm{~B}_{2}, \mathrm{G}_{1}\right. \\
\left.\text { and } \mathrm{G}_{2}\right)\end{array}$ \\
\hline & & $\begin{array}{l}\text { Tree nuts, other than the } \\
\text { tree nuts listed above and } \\
\text { processed products } \\
\text { thereof intended for } \\
\text { direct human } \\
\text { consumption }\end{array}$ & $\begin{array}{l}2.0(\mathrm{~B} 1) \\
4.0\left(\mathrm{Sum}_{1} \text { of } \mathrm{B}_{1}, \mathrm{~B}_{2}, \mathrm{G}_{1}\right. \\
\left.\text { and } \mathrm{G}_{2}\right)\end{array}$ \\
\hline & & $\begin{array}{l}\text { Cereals including maize } \\
\text { and processed products } \\
\text { thereof }\end{array}$ & $\begin{array}{l}2.0(\mathrm{~B} 1) \\
4.0\left(\mathrm{Sum}_{1} \text { of } \mathrm{B}_{1}, \mathrm{~B}_{2}, \mathrm{G}_{1}\right. \\
\left.\text { and } \mathrm{G}_{2}\right)\end{array}$ \\
\hline & & $\begin{array}{l}\text { Processed cereal based- } \\
\text { foods and baby foods for } \\
\text { infants and young } \\
\text { children }\end{array}$ & $0.10(\mathrm{~B} 1)$ \\
\hline Milk & 0.5 (M1) & $\begin{array}{l}\text { Milk for the manufacture } \\
\text { of milk-based products }\end{array}$ & $0.05(\mathrm{M} 1)$ \\
\hline \multicolumn{4}{|l|}{ Feed } \\
\hline $\begin{array}{l}\text { Cottonseed meal as feed } \\
\text { ingredient }\end{array}$ & 300 & All feed materials except & 20 (B1) \\
\hline $\begin{array}{l}\text { Corn and peanut } \\
\text { products for finishing } \\
\text { beef cattle }\end{array}$ & 300 & $\begin{array}{l}\text { Complete feedingstuffs } \\
\text { for cattle, sheep and } \\
\text { goats }\end{array}$ & 20 (B1) \\
\hline $\begin{array}{l}\text { Corn, peanut products, } \\
\text { cottonseed meal and } \\
\text { other animals feeds for } \\
\text { dairy animals } \\
\end{array}$ & 20 & $\begin{array}{l}\text { Complete feedingstuffs } \\
\text { for dairy feed }\end{array}$ & 5 (B1) \\
\hline $\begin{array}{l}\text { Corn and peanut } \\
\text { products and other } \\
\text { animals feeds (excluding } \\
\text { cottonseed meal) for } \\
\text { immature animals }\end{array}$ & 20 & $\begin{array}{l}\text { Complete feedingstuffs } \\
\text { for calves and lambs }\end{array}$ & 10 (B1) \\
\hline $\begin{array}{l}\text { Corn or peanut products } \\
\text { for finishing swine }\end{array}$ & 200 & $\begin{array}{l}\text { Complete feedingstuffs } \\
\text { for pigs and poultry }\end{array}$ & 20 (B1) \\
\hline
\end{tabular}


Table 4 Mycotoxin risk reduction actions along cereal supply chain

\begin{tabular}{|c|c|c|c|}
\hline Supply Chain Stage & Actions & Impact & Notes \\
\hline \multicolumn{4}{|c|}{ Primary production } \\
\hline Site selection & $\begin{array}{l}\text { Evaluate production site in } \\
\text { terms of seasonal temperature } \\
\text { and precipitation }\end{array}$ & High & $\begin{array}{l}\text { Regions with higher temperatures } \\
\text { and high precipitation often have } \\
\text { higher fungal growth but this is } \\
\text { specific to species e.g. A. flavus is } \\
\text { prevalent in hot humid climes while } \\
P \text {. parasiticus prefers cooler } \\
\text { conditions but both produce } \\
\text { aflatoxins }\end{array}$ \\
\hline $\begin{array}{l}\text { Previous crop and } \\
\text { rotations }\end{array}$ & $\begin{array}{l}\text { Avoid sites that have previously } \\
\text { grown maize or other } \\
\text { susceptible cereal crops, } \\
\text { especially if fungal infestations } \\
\text { detected in previous season. }\end{array}$ & High & $\begin{array}{l}\text { Intensive cereal rotations or } \\
\text { monocultures can lead to carry over } \\
\text { of diseases, pests and fungal spores } \\
\text { that can lead to infection of } \\
\text { subsequent crops. }\end{array}$ \\
\hline $\begin{array}{l}\text { Crop residue } \\
\text { management }\end{array}$ & $\begin{array}{l}\text { If previous crop was susceptible } \\
\text { and may hold fungal spores, } \\
\text { bury residues by soil inversion }\end{array}$ & High & $\begin{array}{l}\text { Burying previous crop results in a } \\
\text { clean seed bed and less risk of fungal } \\
\text { infection. See also weeds }\end{array}$ \\
\hline Variety choice & $\begin{array}{l}\text { Select varieties with higher } \\
\text { levels of fungal resistance if } \\
\text { available. Also crops with } \\
\text { drought, and temperature stress } \\
\text { resistance may be more resistant } \\
\text { to fungal infection. }\end{array}$ & Medium & $\begin{array}{l}\text { Increased genetic resistance to } \\
\text { fungal attack. Earlier ripening } \\
\text { varieties can allow harvesting in } \\
\text { better weather conditions. See also } \\
\text { Harvesting time }\end{array}$ \\
\hline Fertiliser inputs & $\begin{array}{l}\text { Match inputs to crop } \\
\text { requirements and weather } \\
\text { conditions }\end{array}$ & Low & $\begin{array}{l}\text { Excessive fertiliser inputs, especially } \\
\text { nitrogen, can result in crops lodging. } \\
\text { This creates a more humid micro- } \\
\text { climate conducive to fungal growth. } \\
\text { See also growth regulators. }\end{array}$ \\
\hline Growth regulators & $\begin{array}{l}\text { Dose and timing should be at } \\
\text { correct growth stage to ensure } \\
\text { stem elongation is reduced }\end{array}$ & Medium & $\begin{array}{l}\text { Growth regulators result in shorter } \\
\text { crops that can take up more nitrogen } \\
\text { without lodging }\end{array}$ \\
\hline $\begin{array}{l}\text { Fungicide } \\
\text { applications }\end{array}$ & $\begin{array}{l}\text { Detection of outbreaks of ear } \\
\text { blight can be controlled by } \\
\text { fungicides }\end{array}$ & Medium & \\
\hline $\begin{array}{l}\text { Weed \& Insect } \\
\text { Controls }\end{array}$ & $\begin{array}{l}\text { Certain weeds may harbour } \\
\text { fungi and insect pests. Insects } \\
\text { can cause physical damage } \\
\text { allowing a potential route for } \\
\text { fungal infection }\end{array}$ & Low & $\begin{array}{l}\text { Weeds can be a source of fungi in a } \\
\text { similar way to crop residues while } \\
\text { physical damage to the crop by } \\
\text { insects can provide a route for fungi } \\
\text { to enter crops }\end{array}$ \\
\hline $\begin{array}{l}\text { Harvesting and } \\
\text { drying }\end{array}$ & $\begin{array}{l}\text { Test grain moisture content } \\
\text { before harvesting and dry to } \\
\text { below safe moisture content } \\
\text { before longer term storage. } \\
\text { Minimise holding times before } \\
\text { drying is completed }\end{array}$ & Medium & $\begin{array}{l}\text { Maize harvested at } 25 \% \text { m.c. with } \\
\text { delayed drying to }<14 \% \text { m.c. can } \\
\text { have significant growth in } \\
\text { fumonisins and zearalernone. } \\
\text { Other cereals should be dried to } 14- \\
15 \% \text { m.c. }\end{array}$ \\
\hline Harvesting time & $\begin{array}{l}\text { Early maturing varieties allow } \\
\text { for an earlier start to harvesting } \\
\text { in better weather conditions and } \\
\text { spread the throughput of crop } \\
\text { through drying facilities }\end{array}$ & Medium & $\begin{array}{l}\text { Earlier harvests can reduce risk of } \\
\text { fungal infections is weather } \\
\text { conditions deteriorate. }\end{array}$ \\
\hline \multicolumn{4}{|c|}{ Storage } \\
\hline Store design & $\begin{array}{l}\text { Stores should be well designed } \\
\text { and maintained with good } \\
\text { ventilation and airflow through } \\
\text { stored grains }\end{array}$ & High & $\begin{array}{l}\text { Airflow and temperature are critical } \\
\text { to maintaining grains under safe } \\
\text { storage conditions. Any areas with } \\
\text { poor ventilation can become hot- } \\
\text { spots for fungal infection. }\end{array}$ \\
\hline
\end{tabular}




\begin{tabular}{|c|c|c|c|}
\hline $\begin{array}{l}\text { Harvest and store } \\
\text { Hygiene }\end{array}$ & $\begin{array}{l}\text { Cleaning of harvesting, drying } \\
\text { and storage equipment can } \\
\text { reduce spore carry over between } \\
\text { seasons and between crops } \\
\text { within a season }\end{array}$ & High & $\begin{array}{l}\text { Poor hygiene can lead to inoculation } \\
\text { of clean crops with fungal spores. }\end{array}$ \\
\hline $\begin{array}{l}\text { Adequate capacity } \\
\text { for rapid grain drying }\end{array}$ & $\begin{array}{l}\text { High capacity reduces the risk } \\
\text { of a backlog of higher moisture } \\
\text { content grain in temporary } \\
\text { storage. The aim is to dry below } \\
18 \% \text { m.c. as quickly as } \\
\text { possible. }\end{array}$ & High & $\begin{array}{l}\text { If grain is stored above } 18 \% \text { m.c. } \\
\text { then the risk of ochratoxin } \mathrm{A} \text { is } \\
\text { increased during storage. }\end{array}$ \\
\hline Rapid cooling & $\begin{array}{l}\text { Fungal growth can be inhibited } \\
\text { if grains are cooled and } \\
\text { maintained cool }\end{array}$ & High & $\begin{array}{l}\text { Rapid cooling to below } 15^{\circ} \mathrm{C} \text { reduces } \\
\text { fungal activity }\end{array}$ \\
\hline $\begin{array}{l}\text { Continued drying and } \\
\text { cooling }\end{array}$ & $\begin{array}{l}\text { Dry grains to recommended safe } \\
\text { storage moisture content. Long } \\
\text { term cooling to } 5^{\circ} \mathrm{C}\end{array}$ & Medium & $\begin{array}{l}\text { Other fungi are restricted at lower } \\
\text { m.c. and temperature See also } \\
\text { Harvesting and drying. }\end{array}$ \\
\hline $\begin{array}{l}\text { Grain store } \\
\text { monitoring }\end{array}$ & $\begin{array}{l}\text { Continued monitoring of } \\
\text { temperature, moisture content } \\
\text { and insect/mite activity }\end{array}$ & Low & $\begin{array}{l}\text { Monitoring enables any problems to } \\
\text { be detected and acted on } \\
\text { immediately. }\end{array}$ \\
\hline \multicolumn{4}{|c|}{ Processing } \\
\hline Milling & $\begin{array}{l}\text { Milling can redistribute } \\
\text { mycotoxins into different } \\
\text { fractions of the process }\end{array}$ & Medium & $\begin{array}{l}\text { Dry milling results in more } \\
\text { fumonisins , zearfalernone, DON, } \\
\text { aflatoxins and ochrtixin A in the } \\
\text { bran used for animal feed as opposed } \\
\text { to fractions used for food. } \\
\text { Wet milling results in more } \\
\text { fumonisins, zearalernone and } \\
\text { aflatoxin in the steep water as } \\
\text { opposed to milled products. }\end{array}$ \\
\hline Brewing & $\begin{array}{l}\text { Mycotoxins may transfer from } \\
\text { contaminated grain to the beer } \\
\text { during the brewing process }\end{array}$ & High & $\begin{array}{l}\text { Aflatoxins, ochratoxin A, } \\
\text { zearalernone, DON and fumonisins } \\
\text { can withstand the brewing process } \\
\text { including the boiling of the wort } \\
\left(100^{\circ} \mathrm{C}\right) \text {. Reductions in mycotoxins } \\
\text { from brewing range from } 2-28 \% \text {. }\end{array}$ \\
\hline Thermal processing & $\begin{array}{l}\text { Cooking of products can } \\
\text { denature some mycotoxins. } \\
\text { Processes may include boiling } \\
\text { (as with brewing), roasting, } \\
\text { bakoing and frying. }\end{array}$ & High & $\begin{array}{l}\text { Aflatoixins may be reduced by } \\
\text { cooking }(30 \%) \text {, pressure cooking } \\
(80 \%) \text { and frying ( } 35 \%) \text {. Roasting at } \\
150^{\circ} \mathrm{C} \text { for } 120 \text { mins reduced } \\
\text { aflatoxins by } 63 \% \text {. } \\
\text { Ochartoxin A denatured at temps > } \\
250^{\circ} \mathrm{C} \\
\text { Fumonisins denature at tems > } \\
150^{\circ} \mathrm{C}\end{array}$ \\
\hline Extrusion & $\begin{array}{l}\text { Extrusion is a process often } \\
\text { used for cereals and snack foods } \\
\text { which includes thermal } \\
\text { processes. This can denature } \\
\text { some mycotoxins }\end{array}$ & High & $\begin{array}{l}\text { Extrusion temperatures can reach } \\
160 \text { oC or higher for a short period. } \\
\text { This can result in denaturing of those } \\
\text { mycotoxins that are susceptible to } \\
\text { these temperatures. The reduced } \\
\text { heating tome may however, reduce } \\
\text { the efficacy of this heat process }\end{array}$ \\
\hline
\end{tabular}

